\title{
Bridging the implementation gap: Combining backcasting and policy analysis to study renewable energy in urban road transport
}

Linda Olsson, Linnea Hjalmarsson, Martina Wikström and Mårten Larsson

\author{
Linköping University Post Print
}

Tweet

N.B.: When citing this work, cite the original article.

Original Publication:

Linda Olsson, Linnea Hjalmarsson, Martina Wikström and Mårten Larsson, Bridging the implementation gap: Combining backcasting and policy analysis to study renewable energy in urban road transport, 2015, Transport Policy, (37), 72-82.

http://dx.doi.org/10.1016/j.tranpol.2014.10.014

Copyright: Elsevier

http://www.elsevier.com/

Postprint available at: Linköping University Electronic Press

http://urn.kb.se/resolve?urn=urn:nbn:se:liu:diva-112506 
Bridging the implementation gap: Combining backcasting and policy analysis to study renewable energy in urban road transport

Linda Olsson ${ }^{\mathrm{a}, *}$, Linnea Hjalmarsson $^{\mathrm{b}}$, Martina Wikström ${ }^{\mathrm{c}}$, Mårten Larsson ${ }^{\mathrm{c}}$

${ }^{a}$ Department of Management and Engineering, Division of Energy Systems, Linköping University, SE-58183 Linköping, Sweden

${ }^{b}$ Department of Thematic Studies, Division of Technology and Social Change, Linköping University, SE-58183 Linköping, Sweden

${ }^{\mathrm{c}}$ Department of Chemical Engineering and Technology, Division of Energy Processes, KTH Royal Institute of Technology, Teknikringen 42, SE-10044 Stockholm, Sweden

*Corresponding author:

Linda Olsson

Department of Management and Engineering, Division of Energy Systems, Linköping University, SE-58183 Linköping, Sweden

Tel.: +4613285664

E-mail: linda.olsson@liu.se (L. Olsson) 


\section{Abstract}

This paper combines backcasting and policy analysis to identify the opportunities for and barriers to the increased use of renewable energy and energy-efficient vehicles in an urban road transport system, namely, that of Stockholm, Sweden, in 2030. The combination of methods could bridge the implementation gap between scenario-based research and actual policy implementation and thus increase the chances of research being implemented in practice. In the case study, backcasting identifies a need for diverse fuels and vehicles and for immediate policy action. However, analysis of policy integration demonstrates that such action is unlikely given current policy structures. The fundamental lack of integration between energy and transport policy obstructs measures to increase the use of renewable fuels and more energy-efficient vehicles, which in turn obstructs the reduction of $\mathrm{CO}_{2}$ emissions from transport. The combination of backcasting and policy analysis is demonstrated to improve our understanding of the prerequisites for transitioning to a system based on renewable energy, and could thus be useful in further research.

Keywords: Urban road transport, Renewable fuels, Energy efficiency, Transport policy, Energy policy, Scenario studies

\section{Introduction}

Urban road transport is the source of several environmental and human health problems. Due to its $98 \%$ dependency on fossil fuels, road transport is a major source of the anthropogenic $\mathrm{CO}_{2}$ emissions that contribute to climate change (IEA, 2011). In urban areas, additional problems are noise and reduced air quality due to local emissions of particulate matter and nitrogen oxides. As urbanization is a global trend that is assumed to continue (World Bank, 2008), it is imperative to reduce the negative impact of urban road transport. In the European Union (EU), measures targeting this include the increased use of renewable fuels and more energy-efficient vehicle technologies (EC, 2011a,b). By 2030, the aim is to reduce the number of fossil-fuelled cars in urban transport by half in the EU (EC, 2011a).

Current road transport policy can be interpreted as implying that 'renewable fuels' refer to biofuels ${ }^{1}$ and that 'energy-efficient technologies' refer to plug-in electric vehicles. The share of biofuels is low in the EU, just over 4\% of energy use in road transport in 2010 (Ecofys, 2012), but there are opportunities to greatly increase this share. Several different biofuels can be produced from a wide range of feedstocks, and there is considerable future potential for energy-efficient production in large volumes (Lindfeldt et al., 2010; Swedish Government, 2013). The diversity of biofuels could provide more or less individual energy and resourceefficient solutions for different transport needs. Currently, plug-in electric vehicles are even less common than are biofuelled ones. As they are far more energy efficient than conventional cars, are silent, and lack tailpipe emissions, they are a desirable alternative in urban traffic (EC, 2011a). With renewable electricity generation, electric vehicles could also contribute to $\mathrm{CO}_{2}$ emission reductions.

\footnotetext{
${ }^{1}$ In this paper the terms biofuel and fossil fuel are used exclusively, although in Sweden petrol and diesel have a $5 \%$ biofuel blend-in and are thus not purely fossil.
} 
Scenario-based research suggests that biofuels and plug-in electric vehicles could meet future transport demand in whole countries and in urban areas (Lindfeldt et al., 2010; Robèrt et al., 2007; Turton, 2006). Some studies also acknowledge the need for behavioural change and reduced transport demand as important factors in addition to technological improvements (Åkerman and Höjer, 2006; Hickman and Banister, 2007; Robèrt and Jonsson, 2006). A common denominator of all these studies is that they focus on the ability of technology to create a desired, ideal future; economic conditions are sometimes considered, but societal factors rarely are.

The purpose of scenario studies is usually to initiate radical change, for instance towards greater sustainability (Banister and Hickman, 2013; Robinson, 1990). However, there is a gap between scenario-based research and actual policy implementation (Banister and Hickman, 2013). One way of bridging this gap and bringing research into policy-making could be to modify the research process. According to Nilsson et al. (2011), scenario studies are unrealistic as long as they ignore political conditions. Although scenario studies provide valuable information, they provide insufficient guidance on reaching sustainability goals. Greater attention to how to actually reach the desired future is needed, and this entails understanding relevant societal and political conditions (Nilsson et al., 2011). An analysis of current policy-making could illuminate the actual possibilities for realizing future scenarios. Thus, the gap between research and policy implementation could be diminished.

This paper combines a backcasting study of urban road transport with an analysis of current policy processes in Stockholm, Sweden. The desired future includes increased use of renewable fuels and energy-efficient technologies in the road transport system as means to reduce $\mathrm{CO}_{2}$ emissions from road transport in line with EU goals. The policy analysis focuses on integration between transport and energy policy, as vehicles and fuels are managed in these two policy sectors. Research demonstrates that policy integration can greatly affect the outcome of policy processes (Underdal, 1980). Policy integration has been shown to be of importance for sustainable transport (Banister, 2008; Hull, 2011). A policy integration analysis can identify the ability of a policymaking structure to advance the realization of future scenarios. In this paper, integration between policy sectors is of greater interest than integration between specific institutions, wherefore the results can be considered generalizable.

This paper has two aims:

- To identify the characteristics of current policy that could hinder the increased use of renewable fuels and energy-efficient technologies in Stockholm's road transport system. This is done by identifying how policy correlates with desired future scenarios.

- To demonstrate a useful methodology for improved understanding of the prerequisites for future scenarios, by using the interdisciplinary combination of policy integration analysis and backcasting in a case study.

The case study object is Stockholm, the Swedish capital, a metropolitan area with approximately 2 million inhabitants (Eurostat, 2012).Motorized road transport is a large and 
important issue in this area despite a fairly high degree of public transport ${ }^{2}$ utilization, initiatives to increase walking and cycling, and congestion charges for driving automobiles into the city centre. Sweden has fairly ambitious goals to reduce fossil fuel dependency in the transport system through using biofuels and plug-in electric vehicles (Swedish Government, 2009). There is also a policy framework for the sustainable development of road transport in the Stockholm region, in line with the ambitious national goals. Due to a dominant share of hydro and nuclear power in Swedish electricity generation, the introduction of plug-in electric vehicles is considered one way to reduce $\mathrm{CO}_{2}$ emissions from road transport. Biofuels are produced and used to some extent. Existing technological conditions are therefore supportive of a 'renewable future'. Thus, Stockholm makes an interesting case with regard to implementation of policy for renewable fuels and energy-efficient vehicles. By analysing a situation in which technology development is not a major obstacle, the importance of the policy process should become clear.

\section{Background}

Backcasting is increasingly popular in studies of future energy use, energy supply and climate impact. This highly normative tool is usually used with the aim of radical change (Banister and Hickman, 2013; Robinson, 1990), and as such it has been used to examine how the transport system could evolve in several countries and cities, in order to reach sustainability goals. In a Swedish backcasting study, Åkerman and Höjer (2006) establish that for a transport system that complies with the $450 \mathrm{ppm} \mathrm{CO}_{2}$ target for 2050, substantial social change is required. Lindfeldt et al. (2010) present strategies for renewable road transport in Sweden 2025, concluding that a mix of demand reduction and technical improvements could lead to a road transport system without fossil fuels. Robèrt et al. (2007) investigate the possibility of relying solely on biofuels in road transport in Stockholm County in 2030. They conclude that such a future would be possible, but also point out the importance of demand reduction (Robèrt et al., 2007). The importance of a combination of technical progress and demand reduction is confirmed by backcasting studies in many other developed countries and regions, for instance California, Japan and the UK (Ashina et al., 2012; Hickman and Banister, 2007; Yang et al.; 2009).

A more sustainable transport system is shown to be possible, through a combination of technology measures and social change. But how plausible is the implementation of the suggested policy implications? To what degree can backcasting studies lead to a more sustainable transport system? The studies mentioned above focus on technological and economic conditions, as is common in backcasting studies (Robinson, 1990). However, the outcome of the studies reveals policy implications concerning not only technology but also behaviour and social structure. Not accounting for societal conditions in a study that then concludes that social change is needed might affect the implementation of policy for social change. While the desired scenarios of a backcasting study can be used to visualize opportunities and instigate change, the actual workings of the policy process can provide important constraints to the implementation of change.

\footnotetext{
${ }^{2}$ In Stockholm, public transport comprises a metro system, buses and commuter trains
} 
In studies of sustainable urban transport, the policy process is often found problematic. For example, in a study of a major road investment in Stockholm County, the so called Bypass Stockholm, Finnveden and Åkerman (2014) found that long-term environmental sustainability goals were not included in the planning process. An alternative to Bypass Stockholm, that would include demand reduction measures such as investment in public transport and congestion charges, was found to be more environmentally sustainable. The alternative was rejected by the planners as "the goal was to find a road corridor, not to find the best solution for Stockholm's traffic and transport problems" (Finnveden and Åkerman, 2014 p. 54). In line with this, a study of two British regions, centred around London and Oxford respectively, call for coherent and long-term planning strategies for more sustainable transport to be achievable (Hickman et al., 2013).

Several other aspects of complications in the policy process are found in international literature. A Finnish study of transport policy goals and implementation found that goals were sometimes conflicting, but also that there were often dependencies between goals, and between goals and policy measures. This could obstruct the policy process (Tuominen and Himanen, 2007). A Canadian study of institutional integration with regard to urban transport policy found that planners and policy-makers find it difficult to implement change (Hatzopoulou and Miller, 2008). Poor integration between institutions, vertically (e.g. between national and regional institutions) as well as horizontally (e.g. between regional actors), was also identified as an obstacle to planning for sustainable transport (Hatzopoulou and Miller, 2008). Marsden et al. (2014) conclude that concerning climate change goals, not only is the transport policy process slow and incremental, but that it might be difficult to change this pattern.

Could awareness of these possible obstructions to changes in the policy process increase the chances of successful implementation of backcasting studies? Research on the topic of backcasting has established the importance of connecting to the policy process in order to improve usefulness (Banister and Hickman, 2013; Nilsson et al., 2011; Robinson, 1990). Banister and Hickman (2013) describe how scenario studies, defining desirable futures and how to reach them, may bridge the implementation gap between research and the policy process. Although their focus is on the powerfulness of using scenarios to achieve substantial change, they also recognise that realism should be included in the scenario analysis (Banister and Hickman, 2013). A solid foundation with regard to the policy process could increase the realism and thus possibly increase the plausibility of implementing policy implications derived from a backcasting study.

In this study, backcasting is combined with an analysis of policy integration as an attempt to bridge the implementation gap by addressing the plausibility of implementation of policy implications. In a worst case scenario the policy process is slow, inert, poorly integrated with regard to goals as well as involved actors, and based on short-term strategies. Slowness may be inevitable (Marsden et al., 2014), but possibility for improvement can be found in policy integration (see e.g. Anderton, 2010; Stead, 2008). Thus, connecting policy integration to a backcasting study could be a fruitful way of bridging the implementation gap identified by Banister and Hickman (2013). 


\section{Materials and methods}

This interdisciplinary study uses two approaches. To explore Stockholm's regional policy processes and understand policy integration, documents were studied and interviews held with key civil servants in the energy and transport policy sectors. To obtain a view of a desired future road transport system in Stockholm in 2030, a backcasting study was conducted. This section presents the methods used and the material on which the paper is based.

\subsection{Methods used for the policy analysis}

In Stockholm County, energy and transport policy is handled by several institutions with different responsibilities. For a basic understanding of the actors involved in the policy process and the relations between them, Figure 1 gives an overview of the Swedish governing system. Stockholm County encompasses 26 municipalities, with City of Stockholm in the urban centre being the most populated municipality. Therefore, City of Stockholm is the only municipality to be represented specifically in this study.

\begin{tabular}{|c|c|c|}
\hline National level & $\begin{array}{l}\text { Parliament } \\
\text { Legislative power } \\
\text { (Publicly elected) }\end{array}$ & $\begin{array}{l}\text { Government } \\
\text { Executive power }\end{array}$ \\
\hline County level & \multicolumn{2}{|c|}{$\begin{array}{l}\text { County Administrative Boards } \\
\text { Coordinates development in line with } \\
\text { the goals of parliament and goverment, } \\
\text { concerning e.g. traffic, infrastructure, } \\
\text { energy and climate }\end{array}$} \\
\hline
\end{tabular}

\begin{tabular}{ll|}
\cline { 2 - 2 } Municipal level & $\begin{array}{l}\text { Municipalities } \\
\text { Responsible for certain societal } \\
\text { functions, e.g. energy supply and } \\
\text { local environment } \\
\text { (Publicly elected) }\end{array}$ \\
\hline
\end{tabular}

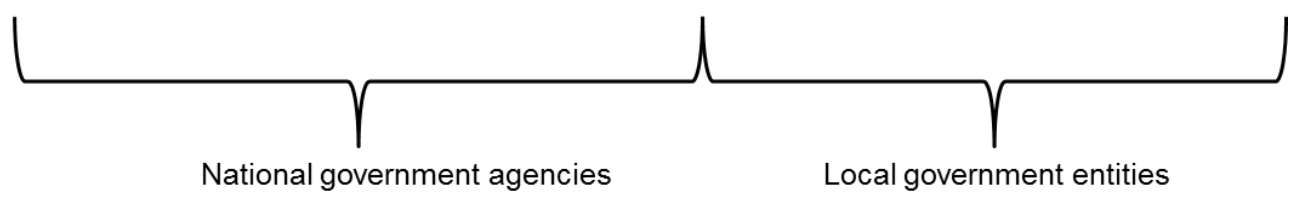

Figure 1. The Swedish governing model, with regard to transport, energy and environmental issues.

Document analysis is highly appropriate in qualitative case studies (Bowen, 2009). It is relevant in this case as documents represent the written part of policy, providing timestamps for the policy process. In addition, as the documents are archived and thereby available to the public, the research process becomes transparent. In this study, documents were selected based on two criteria:

- that they treat transport or transport planning in the Stockholm region

- that they were issued or updated between 2007 and 2011 
These criteria led to the selection of the five documents presented in Table 1. Some of these documents are authoritative and govern regional planning, while others are intended to guide and inspire decision-making. The different document types provide a broad overview of current policy perspectives.

Table 1. Overview of the studied documents.

\begin{tabular}{|c|c|c|c|c|}
\hline Ref. & Document title & Issuing institution & Policy sector & Scope \\
\hline D1 & $\begin{array}{l}\text { Regional development plan for } \\
\text { the Stockholm region: RUFS } \\
2010^{\mathrm{a}}\end{array}$ & $\begin{array}{l}\text { Stockholm County } \\
\text { Council - Office of } \\
\text { Regional Planning }\end{array}$ & $\begin{array}{l}\text { Transport and } \\
\text { energy policy }\end{array}$ & $\begin{array}{l}\text { - Guiding } \\
\text { - Regional }\end{array}$ \\
\hline D2 & $\begin{array}{l}\text { Energy future of the Stockholm } \\
\text { region 2010-2050: the way to } \\
\text { reduce climate impact }{ }^{\text {b }}\end{array}$ & $\begin{array}{l}\text { Eleven regional private } \\
\text { and public actors in } \\
\text { collaboration }\end{array}$ & $\begin{array}{l}\text { Energy policy, with } \\
\text { transport aspects }\end{array}$ & $\begin{array}{l}\text { - Guiding } \\
\text { - Regional }\end{array}$ \\
\hline D3 & $\begin{array}{l}\text { Joint transport solution for } \\
\text { environment and development in } \\
\text { the Stockholm region: until } 2020 \\
\text { and towards } 2030^{c}\end{array}$ & $\begin{array}{l}\text { Swedish government in } \\
\text { cooperation with } \\
\text { regional public actors }\end{array}$ & $\begin{array}{l}\text { Transport policy, } \\
\text { focus on } \\
\text { infrastructure }\end{array}$ & $\begin{array}{l}\text { - Governing } \\
\text { - Regional }\end{array}$ \\
\hline D4 & $\begin{array}{l}\text { County plan for regional transport } \\
\text { infrastructure in Stockholm } \\
\text { County } 2010-2021^{\mathrm{d}}\end{array}$ & $\begin{array}{l}\text { Stockholm County } \\
\text { Administration Board }\end{array}$ & $\begin{array}{l}\text { Transport policy, } \\
\text { focus on } \\
\text { infrastructure }\end{array}$ & $\begin{array}{l}\text { - Governing } \\
\text { - Regional }\end{array}$ \\
\hline D5 & Stockholm city plan $2010^{\mathrm{e}}$ & City of Stockholm & $\begin{array}{l}\text { Energy and } \\
\text { transport policy }\end{array}$ & $\begin{array}{l}\text { - Guiding } \\
\text { - Municipal }\end{array}$ \\
\hline
\end{tabular}

${ }^{\mathrm{a}}$ Office of Regional Planning (2010)

${ }^{\mathrm{b}}$ Office of Regional Planning (2009)

c Stockholmsförhandlingen (2007)

d Stockholm County Administration Board (2010)

${ }^{\mathrm{e}}$ City of Stockholm (2010)

Interviews provide an opportunity to delve deeper into the material found in the document analysis (Bowen, 2009); in addition, background questions can be asked touching, for example, on why an issue was raised or a decision made (Kvale, 1996). In the present study, interviews were used to obtain information about the values and reasoning underlying statements in the documents, about how the documents are perceived (e.g. as guiding vs. prescriptive) by those using them in their work, and about how policy expressed in the documents is implemented.

Interviews were performed with five civil servants who have an implementing role and/or are responsible for issuing and updating policy. The respondents (presented in Table 2), who represent a wide range of transport system issues, have different professions and work in different institutions. The interviews, which were semi-structured with a low level of standardization (Kvale, 1996), lasted about an hour; they were recorded and transcribed. 
Table 2. Interview respondents.

\begin{tabular}{llll}
\hline Ref. & Job title & Workplace & Responsibilities \\
\hline I1 & Project manager & City of Stockholm & $\begin{array}{l}\text { Introducing renewable fuels and new vehicle } \\
\text { technologies }\end{array}$ \\
\hline I2 & City planner & City of Stockholm & Developing the Stockholm city plan (D5) \\
\hline I3 & Senior administrator & $\begin{array}{l}\text { Stockholm County Assn. } \\
\text { of Local Authorities }\end{array}$ & $\begin{array}{l}\text { Environmental and social development } \\
\text { issues }\end{array}$ \\
\hline I4 & Analyst & Stockholm County & $\begin{array}{l}\text { Introducing renewable energy in the regional } \\
\text { transport system }\end{array}$ \\
\hline I5 & Transport strategist & Stockholm County & $\begin{array}{l}\text { Developing the county plan for transport } \\
\text { infrastructure (D4) }\end{array}$ \\
& & Administration Board &
\end{tabular}

\subsection{Backcasting}

Backcasting is a method in which possible future scenarios are formulated and used in developing strategies for realizing a desired future (Dreborg, 1996; Hughes and Strachan, 2010; Quist and Vergragt, 2006; Robinson, 1990). This method is considered particularly useful when the business-as-usual case is no longer good enough and drastic changes are required in order to reach environmental, energy, or climate goals (Höjer and Mattson, 2000). Often, highly polarized scenarios are developed, to illuminate various possible pathways (Dreborg, 1996). Backcasting results are suitable for presentation to decision-makers, as they paint a picture of both the future and how to get there.

This paper uses backcasting in a slightly different way than is usually done. Here, backcasting is used to identify the outcomes of two future scenarios and the strategies required to reach them. The scenarios illustrate two versions of a road transport system without fossil fuels in Stockholm in 2030, one emphasizing biofuels used in internal combustion engine vehicles and the other plug-in electric vehicles. This selection was based on the current interest in biofuels and plug-in electric vehicles observable in Swedish and European policy (EC, 2011a; Swedish Government, 2009). The scenarios are then used to identify implications for policy from working towards them. When these implications are compared with current policy implementation, constraints that should have been included in the backcasting could become visible. Thus, backcasting is in this paper used as a tool to improve backcasting studies rather than as a way of reaching a desired future.

In a Swedish context, some biofuels are considered more likely to be introduced than are others. A literature study was conducted to assess the substitution potential of several alternative fuels by 2030 with regard to technology development, production capacity, distribution systems, and trading volumes. Based on that literature study, ethanol, biomethane, biodiesel/synthetic diesel, dimethyl ether (DME), and renewable electricity are considered likely fuel options in Sweden by 2030. The main rationales for these renewable fuels are presented in Table 3. This study does not take issues of biofuel unsustainability into consideration. It has been shown that biofuels do not always reduce $\mathrm{CO}_{2}$ emissions compared to fossil fuels (see e.g. Fargione et al., 2008; Searchinger et al., 2008), but here a sustainable biofuel production is assumed. Similarly, electricity produced with fossil fuels cannot be 
considered a renewable fuel, but in this paper Swedish, fossil-free electricity production is assumed.

Table 3. Rationales for using selected fuels in the backcasting study.

\begin{tabular}{|c|c|}
\hline Fuel & Main rationales \\
\hline Ethanol & $\begin{array}{l}\text { Current fuel option in Sweden with well-developed distribution system }{ }^{\mathrm{a}} \\
\text { Several future production paths }{ }^{\mathrm{b}}\end{array}$ \\
\hline $\begin{array}{l}\text { Biomethane - biogas and } \\
\text { synthetic natural gas (SNG) }\end{array}$ & $\begin{array}{l}\text { Biogas from anaerobic digestion of organic matter is a currently available vehicle } \\
\text { fuel }^{\text {a }} \\
\text { Distribution system developed in the Stockholm region }{ }^{\mathrm{c}} \\
\text { Several possible future applications }{ }^{\mathrm{d}}\end{array}$ \\
\hline $\begin{array}{l}\text { Biodiesel and synthetic } \\
\text { diesel }\end{array}$ & $\begin{array}{l}\text { Current fuel option in Sweden with well-developed distribution system }{ }^{\mathrm{a}} \\
\text { Only minor modifications to petro-diesel engine are required }\end{array}$ \\
\hline Dimethyl ether (DME) & $\begin{array}{l}\text { Demonstration sites for production exist }{ }^{\mathrm{c}} \\
\text { May contribute significantly to reducing } \mathrm{CO}_{2} \text { emissions from heavy transport }{ }^{\mathrm{f}}\end{array}$ \\
\hline Electricity & $\begin{array}{l}\text { Considered important to increase energy efficiency in the transport sector }{ }^{\mathrm{g}} \\
\text { Low } \mathrm{CO}_{2} \text { emissions given Swedish power generation }{ }^{\mathrm{a}} \\
\text { No tailpipe emissions from plug-in electric vehicles }\end{array}$ \\
\hline
\end{tabular}

${ }^{a}$ SEA (2012)

${ }^{\mathrm{b}}$ Lindfeldt et al. (2010)

${ }^{c}$ SEA (2013)

${ }^{\mathrm{d}}$ Mohseni et al. (2013)

e Basha et al. (2008) and Marchetti (2012)

${ }^{\mathrm{f}}$ Wetterlund et al. (2011) and Pettersson and Harvey (2011)

${ }^{g}$ EC (2011a)

Aside from the difference in fuels, the transport system is assumed to be equivalent in both scenarios. The scenarios have the same predicted transport demand and vehicle fleet composition, as presented in Table 4. Fuel economy, also presented in Table 4, is assumed to be the same in both scenarios. The road transport system in Stockholm in 2030 is assumed to resemble that of 2010. Although population growth is expected, reduced road travel demand is also deemed likely (City of Stockholm, 2007; Lindfeldt et al., 2010), so 2010 travel demand statistics are used. A 25\% improvement in fuel economy is assumed between 2010 and 2030 due to vehicle research and development (Lindfeldt et al., 2010). In the backcasting, the focus is on the urban centre of the Stockholm region, i.e. the City of Stockholm. This part of Stockholm has the most inhabitants and also the greatest transport demand. 
Table 4. Assumptions for the City of Stockholm's road transport system and the fuel economy of vehicle technologies in 2030.

\begin{tabular}{|c|c|c|c|c|c|c|c|}
\hline & & $\begin{array}{c}\text { Light } \\
\text { passenger } \\
\text { vehicles }^{\mathrm{c}}\end{array}$ & $\begin{array}{c}\text { Heavy } \\
\text { passenger } \\
\text { vehicles }^{\mathrm{d}}\end{array}$ & $\begin{array}{l}\text { Light-duty } \\
\text { vehicles }^{\mathrm{e}}\end{array}$ & $\begin{array}{l}\text { Heavy-duty } \\
\text { vehicles }^{f}\end{array}$ & Buses $^{\mathrm{e}}$ & $\begin{array}{l}\text { Motor- } \\
\text { cycles }^{f}\end{array}$ \\
\hline \multirow{2}{*}{$\begin{array}{c}\text { Vehicle } \\
\text { fleet }\end{array}$} & $\begin{array}{l}\text { Annual driving } \\
\text { distance [km] }\end{array}$ & 10,000 & 14,000 & 16,000 & 32,000 & 59,000 & 3000 \\
\hline & No. of vehicles ${ }^{b}$ & 198,000 & 106,000 & 45,000 & 5000 & 1000 & 16,000 \\
\hline \multirow{5}{*}{$\begin{array}{c}\text { Fuel } \\
\text { economy } \\
{[\mathbf{k W h} / \mathbf{1 0 0}} \\
\text { km] }\end{array}$} & Ethanol & 40 & 48 & 78 & 391 & 437 & 48 \\
\hline & Biomethane & 39 & 47 & 81 & 403 & 457 & - \\
\hline & Synthetic diesel & 37 & 44 & 78 & 387 & 447 & 48 \\
\hline & DME & - & - & 76 & 377 & 440 & - \\
\hline & Electricity $^{\mathrm{f}}$ & 16 & 20 & 35 & 150 & 110 & 3 \\
\hline
\end{tabular}

${ }^{a}$ Annual driving distances from Transport Analysis (2013)

${ }^{\mathrm{b}}$ Number of vehicles from SCB (2011)

${ }^{\mathrm{c}}$ Fuel consumption data for 2010 passenger cars from JEC (2011)

${ }^{\mathrm{d}}$ Fuel consumption data for 2010 passenger cars from JEC (2011), with 20\% higher energy consumption due to the higher weight.

${ }^{\mathrm{e}}$ Fuel consumption data from Ahlvik (2008)

${ }^{\mathrm{f}}$ Fuel consumption data from Amjad et al. (2011) and EPRI (2007)

Figure 2 shows the assumed percentages of vehicles using specific fuels in the two scenarios (these distributions are deemed technologically attainable in Stockholm by 2030). The assumptions were made based on a thorough analysis of prognoses for the use of various fuels depending on vehicle technological requirements and use (Bandivadekar et al., 2008; EPRI, 2007; JEC, 2011; Safarianova et al., 2009). Swedish conditions (Swedish Government, 2013) were taken into account when making the assumptions. A certain degree of electrification is assumed even with biofuels dominating the market, and even with extensive electrification not all vehicles are suited for electric motors; these provisos are reflected in the assumed fuel distributions. 


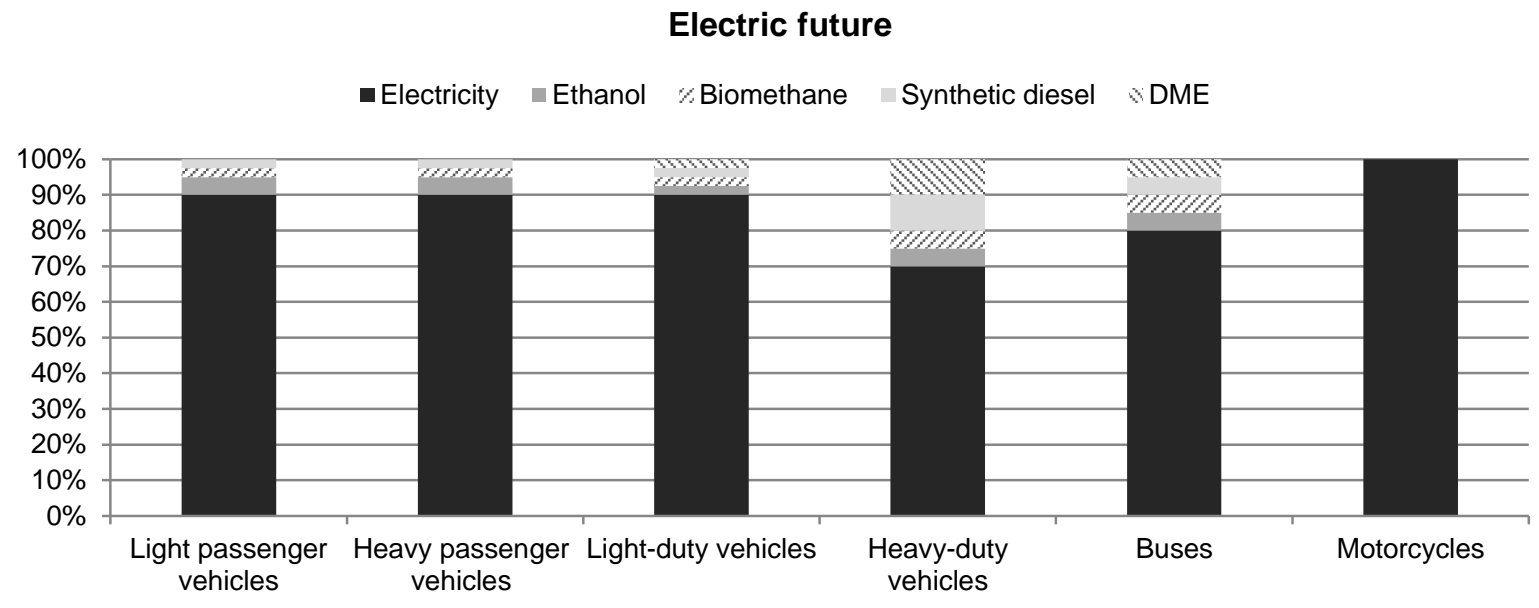

Biofuel future

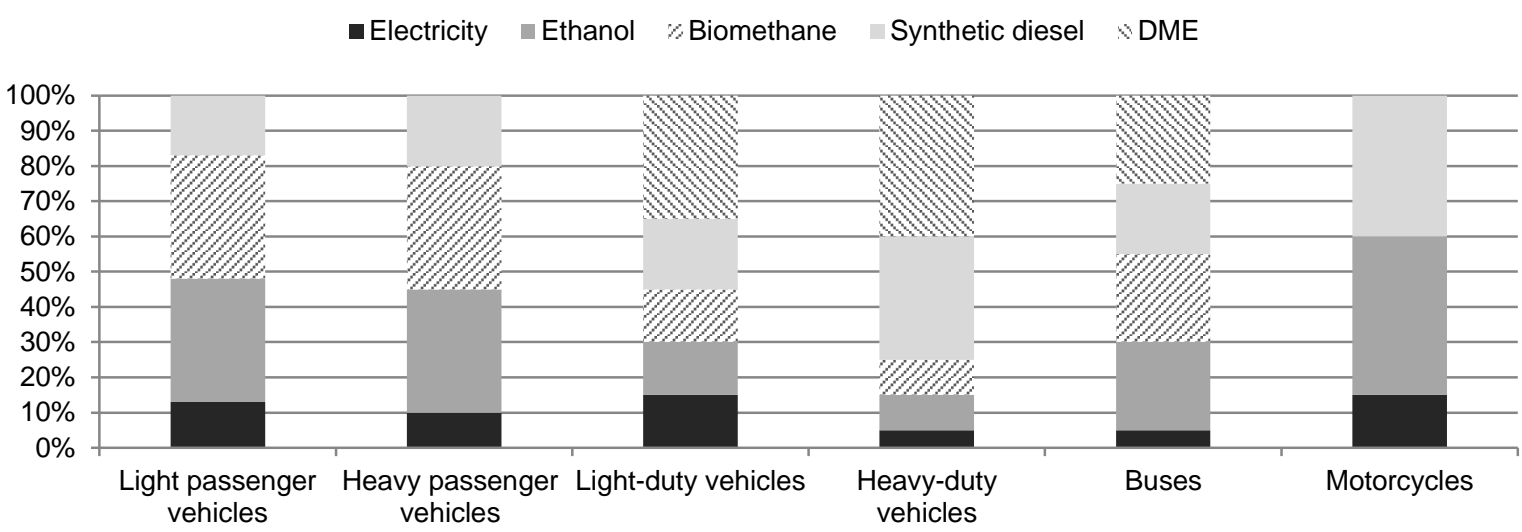

Figure 2. Assumed distributions of fuels in the different vehicle types in the two scenarios.

\section{Backcasting: required modifications to the road transport system}

The backcasting study provides information about the impacts on the energy system of two future scenarios, a biofuel future and an electric future. The energy demand of each fuel in each scenario is shown in Figure 3. Based on this, conclusions about what is required in order to reach these futures can be drawn:

- The road transport system's energy efficiency depends on the degree of electrification of the vehicle fleet. The energy demand could vary greatly depending on the degree of electrification.

- The large-scale introduction of electric vehicles must include support from other renewable fuels. Even with the highest degree of electrification, almost half the energy demand is provided by sources other than electricity.

- Due to fuel supply and vehicle technology constraints, several renewable fuels must be considered. Both visualized possible pathways indicate that no single fuel can meet the whole energy demand alone. 
Energy demand in road transport system by 2030

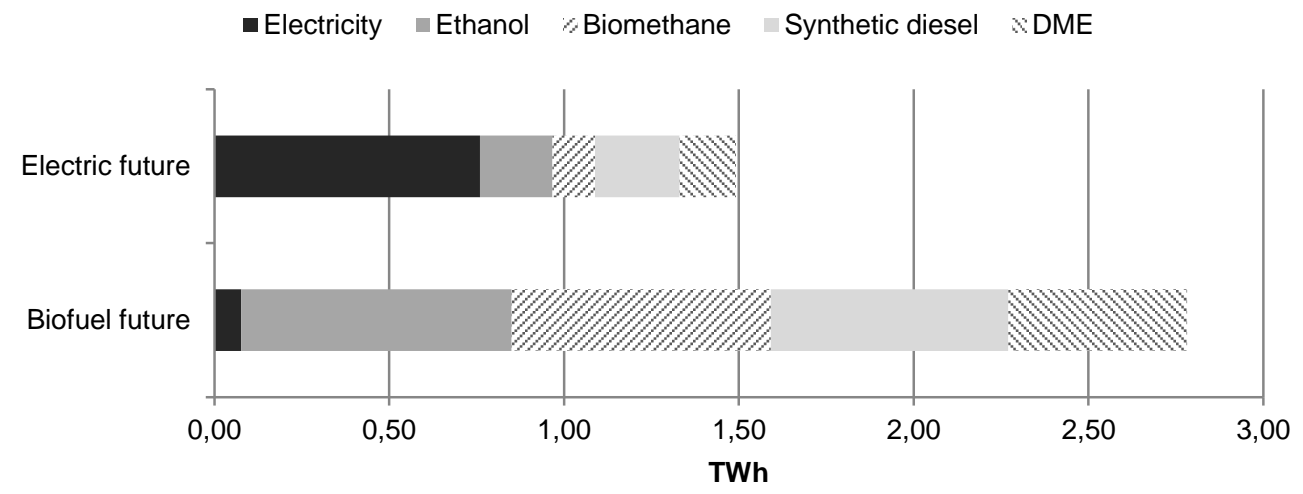

Figure 3. Energy demand, allocated by energy source, for two possible future renewable road transport systems in Stockholm in 2030.

Backcasting studies are often successfully used to visualize how different futures could develop from different initial choices. In the present case, both studied backcast pathways have advantages and disadvantages, so the most desirable future may well be an intermediate one. In a future dominated by biofuels, current vehicle technology could be used and optimized. An electrified future requires the development of new vehicle technologies and battery technology breakthroughs, though both the production and distribution of electricity currently function well. The current biofuel production capacity is limited, and large-scale biofuel production based on fermentation and gasification of lignocellulosic material is probably required in order to meet future demands.

A strategy for substantially increasing renewable energy use in the road transport system therefore requires policy measures to promote biofuel production and distribution as well as new vehicle development. Policy measures to make these new fuels and vehicles attractive to potential users are also required. Although beneficial technological prerequisites for a decarbonized road transport system may exist, that does not mean that new technology will automatically be developed or that, if developed, it will automatically be used in society. Societal and political structures need to facilitate the transition from fossil fuels to renewable energy in road transport.

To substantially increase the use of renewable energy in Stockholm, immediate action is required. Current levels of biofuel and plug-in electric vehicle use are low at approximately 5\% (Swedish Government, 2013) and 2030 is only 16 years away. The average Swedish car is used for 17 years (Swedish Government, 2013), so many conventional vehicles will still be in use in 2030. For the remaining vehicle fleet to use renewable energy to a larger extent than it does now, biofuels and plug-in electric vehicles must be introduced very soon. Policy must be developed with this in mind. 


\section{Policy analysis: integration of transport and energy policy}

\subsection{A theoretical framework for analysing the policy process}

In this paper, public policy is understood as a process comprising the goals, decisions, actions, and inactions that are important in governing a system (Hill, 2005; Jenkins, 1978; Smith, 1976). Policy unfolds via an ongoing process that evolves over time (Hill, 2005; Smith, 1976). Policy processes occur in various policy sectors that each manage issues connected with a particular system. In this paper, the relevant policy sectors are the transport and energy sectors.

Policy processes in different sectors are often parallel, i.e. discussions and decision-making occur simultaneously but independently in several policy sectors. Policy processes in different policy sectors can thus comprise different decisions and actions, even when they treat the same issue. According to Fallde (2011), the transport and energy policy processes are often parallel. Parallelism in the policy process entails the risk of creating contradictory policies. To avoid this, co-ordination between policy sectors is essential (Geerlings and Stead, 2003; Söderberg, 2011), especially for policy sectors concerned with the same problems. In the policy analysis literature, co-ordination between sectors is often called policy integration (Geerlings and Stead, 2003; Persson, 2004). In the present paper, the concept of policy integration is used to frame the co-ordination of policy processes in the transport and energy sectors.

Different parts of the policy process can be considered when analysing policy integration (Howlett, 2009). The present study focuses on the internal characteristics of the policy process, here called problem definitions, policy goals, and policy measures (cf. Rouillard et al., 2013). A problem definition is defined as the representation of a problem that needs to be addressed by public policy. The problem definition can develop, transform, and become concretized in the policy process. Manageable solutions to the concretized problems can become policy goals, which are objectives that policy should aim to achieve. To fulfil policy goals, policy measures are used. A policy measure is an implementable instrument used to manage the system addressed (Rouillard et al., 2013).

Policy integration can occur in all phases of the policy process, and it can be present throughout or in just a small part of the process (Rouillard et al., 2013). Depending on where policy integration occurs, it can have different impacts on policy outcomes. For instance, integrated problem definitions but parallel policy goals and measures could result in incoherent policy implementation. On the other hand, conflicting policy goals but integrated policy measures could still result in integrated policy implementation (Rouillard et al., 2013).

The concepts of problem definition, policy goal, and policy measure are used in the following analysis of energy and transport policy processes in the Stockholm region. These concepts are useful in seeking to understand and explain the relationship between the relevant policy processes and the occurrence of policy integration. 


\subsection{Policy integration in Stockholm}

This section presents, analyses, and discusses energy and transport policy in the Stockholm region using the concepts defined in section 4.1. The policy analysis is based on the document study and the interviews. To clarify the written expressions of policy, the studied documents are summarized in Table 5 (see Table 1 for document descriptions and sources). In the analysis, interviews with civil servants (see Table 2 for interview respondent descriptions) are used to better understand how the documents are interpreted and used in the policy process.

Table 5. Document study findings.

\begin{tabular}{lllll}
\hline Ref. & Policy sector & Scope & Objectives & Instruments \\
\hline D1 & Transport and energy & - Guiding & To maintain mobility without & - Biofuels to reduce \\
& policy & - Regional & increasing climate impact or \\
energy use & - Reduction of local emissions \\
& & & & $\begin{array}{l}\text { by using plug-in electric } \\
\text { vehicles }\end{array}$ \\
& & & & To reduce energy use and \\
\hline D2 & Energy policy, with & - Guiding & - Biogas as a near-future \\
& transport aspects & - Regional & climate impact & solution; electricity as a far- \\
& & & & future solution \\
& & & & - Eco-driving to increase \\
& & & energy efficiency \\
\hline D3 & Transport policy, & - Governing & To increase overall & - Biofuels (mainly biogas) \\
& focus on & - Regional & environmental quality (e.g. & - Increased use of public \\
& infrastructure & climate, air quality) & transport \\
\hline D4 & Transport policy, & - Governing & Framework for infrastructure & - New technology \\
& focus on & - Regional & investments & - Traffic control \\
& infrastructure & & & - Economic policy measures \\
\hline D5 & Energy and transport & - Guiding & To attain a sustainable City of & - Renewable fuels \\
& policy & - Municipal & Stockholm despite increased & - Energy efficiency through \\
& & & population & spatial planning \\
& & & & - Public transport \\
\hline
\end{tabular}

\subsubsection{Transport policy}

The problem definition according to transport policy is the increasing transport demand and associated increasing $\mathrm{CO}_{2}$ emissions. Stockholm's population is expected to grow, requiring more transport availability; meanwhile, climate impact is an important issue and transport is a main contributor to $\mathrm{CO}_{2}$ emissions. As seen in Table 5, the document guiding the development of the entire transport system (D1) specifically emphasizes this problem definition, while the governing documents emphasize narrower problems. Interview respondents confirm that the problem definition is defined in the guiding documents (I1-5).

When the problem definition is transformed and concretized in the policy process, the increased transport demand and maintained mobility come more into focus. Mobility, understood as the availability of transport options for an increasing regional population, is then defined as the policy goal. The other part of the problem definition (i.e. increasing $\mathrm{CO}_{2}$ emissions) is not concretized in the same manner and does not become a policy goal. Mobility is highlighted as the most important policy goal in several transport policy documents (D1, 
D4-5). To maintain mobility, two policy measures are evident: improved road and railway infrastructure, and improved public transport (as seen in Table 5). Improved infrastructure offers more transport options for the increasing population and is assumed to improve mobility. Public transport is also considered a key instrument to maintain mobility as it may reduce congestion.

The policy measure of improved infrastructure relates to the policy goal of mobility, but not to the entire problem definition. The increased population is considered but not increased $\mathrm{CO}_{2}$ emissions. One interview respondent, describing the infrastructure implementation process, confirms that climate impact is not relevant to infrastructure development:

Maybe they do [look into energy issues] indirectly by performing Environmental Impact Assessments, but I wouldn't say that it's high up on the agenda. ... To be honest, that's not how it works. (I2)

The policy measure of public transport relates both to the entire problem definition and to the policy goal. Public transport is considered energy efficient and thus climate friendly, while it could also meet the transport needs of a larger population (D3, D5):

We notice that it's possible to transition to more energy-efficient solutions and resource-efficient solutions, from individual means of transport to more public transport. ... It's much more efficient because you transport so many more people in the same area. (I2)

Public transport is described as a way to increase mobility while transporting more people on existing roads and railways, since land and financial resources are scarce. Increasing use of passenger cars is undesirable due to high energy (currently fossil fuel) use per passenger, so increasing the use of public transport is considered the proper way to achieve more energyand land-efficient transport.

\subsubsection{Energy policy}

Energy policy is concerned with several policy sectors, ${ }^{3}$ one of which is transport (D1-2). The problem definition in energy policy is high energy use, high use of fossil fuels, and, consequently, increasing $\mathrm{CO}_{2}$ emissions (D1-2, D5). Energy use in transport is characterized by fossil fuel use and inefficient combustion engines, both of which are considered contributors to $\mathrm{CO}_{2}$ emissions.

The concretization of the problem definition is centred on maintaining the current road transport system but reducing $\mathrm{CO}_{2}$ emissions. As seen in Table 5, a solution to this problem is to switch to more energy-efficient and less polluting fuels and vehicles. The energy policy goal for transport is then defined as increased energy efficiency and increased use of renewable energy (D2). Policy measures to reach the policy goals are the increased use of

\footnotetext{
3 Namely, energy utilities, the built environment, transportation, industry, agriculture/forestry, and waste management.
} 
biogas ${ }^{4}$ and plug-in electric vehicles. Plug-in electric vehicles are energy efficient and also lack tailpipe emissions. In the City of Stockholm, the congested urban centre where reduction of local air pollution and noise are important issues, plug-in electric vehicles are considered a desirable option. To introduce this new technology in the city, public procurement of plug-in electric vehicles has been initiated (I1). The main aim of this public procurement is to present a consumer base that could attract electric vehicle manufacturers to the Swedish market:

We can charge them using engine heater poles, we have $\mathrm{CO}_{2}$-free electricity, but we don't have the cars. ... We needed to show the vehicle industry that there is a Swedish market and that we have the infrastructure, which they barely knew. So we decided on public procurement of electric vehicles. (I1)

Biogas has been produced and used as vehicle fuel in the Stockholm region for some time and is an established technology. Public and private actors are keen to increase both the production and use of biogas (I3-4). Although biogas can be used to produce heat and electricity, and could thus affect the entire energy system, the focus in Stockholm is strictly on biogas as vehicle fuel (I4).

\subsubsection{Parallel and integrated policy}

In analysing transport and energy policy, some similarities and some differences are apparent. The problem definitions, policy goals, and policy measures are summarized in Table 6 . The problem definitions of both policy sectors partly overlap, but the policy goals and measures differ markedly. This implies some degree of policy integration, but also parallelism, between transport and energy policy.

Table 6. Summary of findings from the policy integration analysis.

\begin{tabular}{llll}
\hline Policy sector & Problem definition & Policy goal & Policy measures \\
\hline Transport policy & $\begin{array}{l}\text { Increasing transport demand and } \\
\text { increasing } \mathrm{CO}_{2} \text { emissions }\end{array}$ & Maintaining mobility & $\begin{array}{l}\text { Infrastructure and public } \\
\text { transport }\end{array}$ \\
\hline \multirow{3}{*}{ Energy policy } & $\begin{array}{l}\text { High energy use and high use of } \\
\text { fossil fuels causing increasing } \\
\mathrm{CO}_{2} \text { emissions }\end{array}$ & $\begin{array}{l}\text { Increased energy } \\
\text { efficiency and increased } \\
\text { use of renewable fuels }\end{array}$ & $\begin{array}{l}\text { Biogas and plug-in } \\
\text { electric vehicles }\end{array}$ \\
\hline
\end{tabular}

Both problem definitions concern increasing $\mathrm{CO}_{2}$ emissions, possibly because they both originate from the same documents, which consider regional development in a holistic manner. This holism implies a common view of what is problematic, which could lead to integration between the policy sectors. However, the problem definitions are handled differently in the two policy processes and lead to different policy goals. The focus on $\mathrm{CO}_{2}$ emissions is lost in transport policy, while energy policy maintains the connection between $\mathrm{CO}_{2}$ emissions and the policy goal. The policy goals in the two sectors are therefore parallel. The policy measures are also parallel, with transport policy focussing on infrastructure and public transport and energy policy focussing on biogas and plug-in electric vehicles.

\footnotetext{
${ }^{4}$ Biogas produced by the anaerobic digestion of organic material such as sewage sludge and household waste is used as natural gas in internal combustion engines.
} 
According to Rouillard et al. (2013), parallel policy goals and measures could result in incoherent policy implementation even if the problem definitions contain the potential for integration. In the present paper, the policy goal of maintaining mobility is not seen as restricted by any energy concerns. When this goal is parallel to the policy goal of increasing renewable fuel use and energy efficiency, a contradictory situation arises: one policy goal is achieved by means of infrastructure, without considering energy use, whereas the other policy goal is achieved by means of energy supply, without considering its use in the system. This parallelism could result in increasing energy use and $\mathrm{CO}_{2}$ emissions, which will not solve the problems as currently defined.

As the problem definitions of energy and transport policy are partly shared, the involved actors may believe that policy goals and measures are also shared even though they are not. The discrepancy between perceived integration and actual lack of integration could complicate or even obstruct solving the problem of increasing $\mathrm{CO}_{2}$ emissions. If actors believe that they are working towards solving the same problem they are unlikely to reassess their work, keeping policy goals and measures separate. A clear focus on the relationship between problem definitions and policy goals could help reduce the separation between policy sectors.

\section{Combining backcasting and policy analysis}

One aim of this paper is to demonstrate how policy analysis can be used to complement backcasting when studying the transition to a desired future. This methodology can identify constraints that should be taken into consideration in backcasting studies, in order to improve their usefulness. Backcasting usually aims at radically changing direction, but if such a change is obstructed by the prevailing policy process, this aim could fail. By acknowledging policy constraints as well as technological or economic constraints, more realistic backcasting studies could be performed. Additionally, backcasting results could be used more productively with knowledge of how the policy process works. Policy analysis reveals complications in decision-making that need to be addressed, thereby emphasizing the implications for policy of desired future scenarios. Combining backcasting and policy analysis could reinforce the transition to a desired future, such as more sustainable urban road transport.

In this paper, the backcasting study demonstrates that, for Stockholm's road transport system to be based on renewable energy, several new fuels and vehicle technologies are required. It is imperative that policy address this issue immediately, as the system needs time-consuming comprehensive modification. This, however, is not supported by the policy process.

The policy analysis reveals a lack of policy integration between energy and transport policy. The two policy sectors are partly integrated in terms of their problem definitions but parallel in terms of their policy goals and policy measures, which entails a risk of contradictory policy goals and measures. In this study, the transport policy goal of maintaining mobility implies that transport infrastructure could be developed without concern for the fuels or vehicle technologies used. In energy policy, the focus is on renewable fuels and energy-efficient vehicles, but the infrastructure to be used by the vehicles is ignored. Failing to address 
infrastructure and energy jointly could lead to greater energy use and greater $\mathrm{CO}_{2}$ emissions caused by more transport, though this may be obscured by the integration of problem definitions: Actors may believe that, because they share the same problem definitions, they are also working towards the same goals.

The policy goals and policy measures analysed here tend to address specific issues rather than applying a comprehensive perspective. Interview respondents almost exclusively discuss biogas and plug-in electric vehicles, although these technologies alone are not enough to build a future transport system based on renewable energy. For instance, there is already a shortage of biogas (Olsson and Hjalmarsson, 2012) and there is little potential to reach the amount that the backcasting study suggests is required by 2030. This will obstruct attainment of the desired future, as a one-sided focus on, for example, biogas means that other renewable fuels and issues, such as energy efficiency, are ignored. Ethanol is another example of the perils of an exclusive policy focus, being mentioned by some interview respondents as a solution of the past:

... so it is electricity and biogas, as ethanol has disappeared somewhere along the way. ... It becomes trends ... (I4)

The respondent remembers an earlier effort to introduce renewable fuels in Sweden that was criticized specifically for favouring ethanol over other fuels (Söderholm, 2012) and for being forced on Swedish local and regional authorities (I3). Ethanol was also criticized by the media, which questioned its sustainability (Motormännen, 2007; Svenska Dagbladet, 2008). These criticisms made ethanol unpopular as a vehicle fuel, although it is still used for blend-in in petrol (SEA, 2012). Such policy-making is clearly counterproductive to achieving a transport system based on renewable energy. A more comprehensive view, not only of problems but also of solutions, is required in order to create the kind of policy called for by the backcasting study.

The backcasting approach is useful in identifying the modifications required in order to reach a desired future. In this case, immediate policy action is essential as large system modifications are required. The policy analysis demonstrates that little action is currently being taken towards substantially reducing $\mathrm{CO}_{2}$ emissions from the road transport system. Awareness of this is important in order to understand how great the challenges really are. The policy process is not easily modifiable as it relies on inflexible structures and traditions. Of course, the goals of other policy sectors might affect the policy process in the transport and energy policy sectors. In addition, numerous actors, private and public, participate in the policy process. Modifying the policy process to get on a pathway suggested by backcasting scenarios might, in this setting, be very slow. Understanding that scenario studies cannot just generate policy to reach desired futures is important in order to avoid unrealistic assumptions about the transition to a road transport system based on renewable energy.

Backcasting studies are sometimes used as tools in policy processes to pinpoint changes and actions needed in order to reach desired futures. However, when dealing with complex problems extending over several policy sectors, backcasting may be more useful if combined with an analysis of policy integration. As this study has demonstrated, an analysis of problem 
definitions, policy goals, and policy measures in different policy sectors can highlight whether the policy process provides appropriate conditions for implementing appropriate measures to reach the desired future. As the case of Stockholm has demonstrated, modifying the road transport system requires not only technological knowledge but also an understanding of the policy process. It would be interesting for further research to study the policy process more closely, in order to better understand the (poor) integration in transport and energy policy in Stockholm.

\section{Conclusions}

This paper has used a case study to demonstrate that combining backcasting with policy integration analysis can successfully identify difficulties encountered in working towards increased renewable fuel use and energy efficiency in urban road transport. The combination of methods is proven useful as it can increase the implementability of backcasting studies. The inclusion of policy analysis can provide more reliable input to backcasting studies, and knowledge of the policy process can help translating results from backcasting studies into policy implications. Thus, combining backcasting and policy analysis could generally be useful in research for a more sustainable future.

In the case of Stockholm's policy process, the fundamental lack of policy integration obstructs measures to reduce $\mathrm{CO}_{2}$ emissions from transport. The backcasting study identifies a need for diverse fuels and vehicles and for immediate policy action. Meanwhile, the policy analysis demonstrates that, given current policy structures, this is difficult to implement.

The findings from the policy integration analysis suggest that Stockholm's policy-makers need to understand the relationship between problem definitions and policy goals and that those do not automatically correspond to each other. In this paper, a mismatch is identified between problem definitions and policy goals. Policy measures are directed towards policy goals but the political rhetoric concerns the problem definitions. In other words, it is possible for policy-makers to be under the impression that they work towards sustainability while the actual policy measures might not address sustainability. Thus, poor policy integration could hamper development towards a more sustainable transport system. Further research should investigate whether this is a general phenomenon or if it is specific for the studied case. This paper also suggests that policy-makers need to understand the problem of an exclusive focus on one or two fuels and/or vehicle technologies; as that could also delay the development of the use of renewable fuels and energy-efficient vehicles.

\section{Acknowledgements}

This paper was written under the auspices of the Energy Systems Programme, which is financed by the Swedish Energy Agency. Thanks are expressed to Magdalena Fallde, Jenny Palm, and Mats Söderström of Linköping University, to Lisa Hansson of the Swedish National Road and Transport Research Institute, to Elisabeth Wetterlund of Luleå University of Technology, and to three anonymous reviewers, for their helpful comments on the paper. 


\section{References}

Ahlvik, P., 2008. Well to wheel efficiency for heavy duty vehicles. Ecotraffic. Available at http://www.pff.nu/upload/EMFO/resultat/Delprogram_6_7/WTW\%20Rapport.pdf. Accessed 2011-08-08.

Åkerman, J., Höjer, M., 2006. How much transport can the climate stand? Sweden on a sustainable path in 2050. Energ Policy 34, 1944-1957.

Amjad, S., Rudramoorthy, R., Neelakrishnan, S., Raja Varman, K.S., Arjunan, T.V., 2011. Evaluation of energy requirements for all-electric range of plug-in hybrid electric twowheeler. Energy 36, 1623-1629.

Anderton, K., 2010. The need for integrated institutions and organizations in transport policy: The case of transport and climate change. In: Givoni, M., Banister, D., (Eds.), Integrated transport: From policy to practice. Oxford, Routledge, pp. 55-74.

Ashina, S., Fujino, J., Masui, T., Ehara, T., Hibino, G., 2012. A roadmap towards a lowcarbon society in Japan using backcasting methodology: Feasible pathways for achieving an $80 \%$ reduction in $\mathrm{CO}_{2}$ emissions by 2050. Energ Policy 41, 584-598.

Bandivadekar, A., Bodek, K., Cheah, L., Evans, C., Groode, T., Heywood, J., Kasseris, E., Kromer, M., Weiss, M., 2008. On the road in 2035: Reducing transportation's petroleum consumption and GHG-emissions. Laboratory for Energy and Environment, Massachusetts Institute of Technology. Report No. LFEE 2008-05 RP.

Banister, D., 2008. The sustainable mobility paradigm. Transp Policy 15, 73-80.

Banister, D., Hickman, R., 2013. Transport futures: Thinking the unthinkable. Transp Policy 29, 283-293.

Basha, S.A., Gopal, K.R., Jebaraj, S., 2008. A review on biodiesel production, combustion, emissions and performance. Renew Sust Energ Rev 13, 1628-1634.

Bowen, G.A., 2009. Document Analysis as a Qualitative Research Method. Qual Res J 9, 27-40.

City of Stockholm, 2007. Ett Stockholm i världsklass - Vision 2030 [A Worldclass Stockholm - the City Vision for 2030]. In Swedish. Stockholm, Sweden.

City of Stockholm, 2010. Promenadstaden - Översiktsplan för Stockholm [Stockholm city plan 2010]. In Swedish.

Dreborg K.H., 1996. Essence of backcasting. Futures 28, 813-828.

EC (European Commission), 2011a. White Paper. Roadmap to a Single European Transport Area-Towards a Competitive and Resource Efficient Transport System. COM/2011/0144 final. Brussels, Belgium. 
EC (European Commission), 2011b. Energy roadmap 2050. COM/2011/885 final. Brussels, Belgium.

Ecofys, 2012. Renewable energy progress and biofuels sustainability. Available at http://ec.europa.eu/energy/renewables/reports/doc/2013_renewable_energy_progress.pdf. Accessed 2013-11-12.

EPRI (Electric Power Research Institute), 2007. Environmental Assessment of Plug-In Hybrid Electric Vehicle. Palo Alto, United States.

Eurostat, 2012. Data collected for larger urban zones. Available at http://epp.eurostat.ec.europa.eu/portal/page/portal/statistics/search_database?_piref458_12095 40_458_211810_211810.node_code=urb_vluz. Accessed 2012-09-18.

Fallde, M., 2011. Miljö i tanken? Policyprocesser vid övergången till alternativa drivmedel i kollektivtrafiken i Linköping och Helsingborg 1976-2005. [Green public transport? Policy processes concerning the transitions to alternative fuels in public transport in Linköping and Helsingborg 1976-2005]. In Swedish. Linköping Studies in Arts and Science No. 534, Linköping University.

Fargione, J., Hill, J., Tilman, D., Polasky, S., Hawthorne, P., 2008. Land clearing and the biofuel carbon debt. Science 319, 1235-1238.

Finnveden, G., Åkerman, J., 2014. Not planning a sustainable transport system. Environ Impact Assess Rev 46, 53-57.

Geerlings, H., Stead, D., 2003. The integration of land use planning, transport and environment in European policy and research. Transp Policy 10, 187-196.

Hatzopoulou, M., Miller, E.J., 2008. Institutional integration for sustainable transportation policy in Canada. Transp Policy 15, 149-162.

Hickman, R., Banister, D., 2007. Looking over the horizon: transport and reduced $\mathrm{CO}_{2}$ emissions in the UK by 2030. Transp Policy 14, 377-387.

Hickman, R., Hall, P., Banister, D., 2013. Planning more for sustainable mobility. J Transp Geogr 33, 210-219.

Hill, M.J., 2005. The public policy process. Harlow, Pearson Longman.

Höjer, M., Mattson, L.G., 2000. Determinism and backcasting in future studies. Futures 32, 613-634.

Howlett, M., 2009. Governance modes, policy regimes and operational plans: a multi-level nest model of policy instrument choice and policy design. Policy Sci 42, 73-89.

Hughes, N., Strachan, N., 2010. Methodological review of UK and international low carbon scenarios. Energ Policy 38, 6056-6065. 
Hull, A., 2011. Transport matters: Integrated approaches to planning city-regions. London, Routledge.

IEA (International Energy Agency), 2011. World Energy Outlook 2011.

JEC (Joint Research Centre-EUCAR-CONCAWE collaboration), 2011. Well-to-wheels analysis of future automotive fuels and powertrains in the European context. EUR 24952 EN.

Jenkins, W.I., 1978. Policy Analysis. London, Martin Robertson.

Kvale, S., 1996. InterViews: An Introduction to Qualitative Research Interviewing. Sage Publications.

Lindfeldt, E.G., Saxe, M., Magnusson, M., Mohseni., F., 2010. Strategies for a road transport system based on renewable resources -The case of an import-independent Sweden in 2025. Appl Energ 87, 1836-1845.

Marchetti, J., 2012. A summary of the available technologies for biodiesel production based on a comparison of different feedstock's properties. Process Saf Environ 90, 157-163.

Marsden, G., Ferreira, A., Bache, I., Flinders, M., Bartle, I., 2014. Muddling through with climate change: a multi-level governance perspective on the transport sector. Clim Policy 14, 617-636.

Motormännen, 2007. Etanol - Dröm eller mardröm. [Ethanol-dream or nightmare]. In Swedish. Available at

https://www.motormannen.se/common/docs/Motor/Motor_artiklar/Artikelarkiv/2007/10/MM 1007_36_38_etanol.pdf. Accessed 2013-12-10.

Mohseni, F., Görling, M., Alvfors, P., 2013. The competitiveness of synthetic natural gas as a propellant in the Swedish fuel market. Energ Policy 52, 810-818.

Nilsson, M., Nilsson, L.J., Hildingsson, R., Stripple, J., Eikeland, P.O., 2011. The missing link: Bringing institutions and politics into energy future studies. Futures 43, 1117-1128.

Office of Regional Planning, 2009. Stockholmsregionens energiframtid 2010-2050 - Vägen till minskad klimatpåverkan. [Energy future of the Stockholm region 2010-2050 - The way to reduce climate impact]. In Swedish.

Office of Regional Planning, 2010. Regional utvecklingsplan för Stockholmsregionen, RUFS 2010 - så blir vi Europas mest attraktiva storstadsregion. [Regional development plan for the Stockholm region - RUFS 2010]. In Swedish.

Olsson, L., Hjalmarsson, L., 2012. Policy for biomass utilisation in energy and transport systems - The case of biogas in Stockholm, Sweden. In Proceedings from World Renewable Energy Forum, WREF 2012, Including World Renewable Energy Congress XII and Colorado Renewable Energy Society (CRES) Annual Conference. Vol. 6, 2012, pp. 4758-4765. 
Persson, A., 2004. Environmental Policy Integration: An Introduction. Stockholm Environment Institute, Stockholm.

Pettersson, K., Harvey, S., 2011. $\mathrm{CO}_{2}$ emission balances for different black liquor gasification biorefinery concepts for production of electricity or second-generation liquid biofuels. Energy 35, 1101-1106.

Quist, J., Vergragt, P., 2006. Past and future of backcasting: The shift to stakeholder participation and a proposal for a methodological framework. Futures 38, 1027-1045.

Robèrt, M., Hultén, P., Frostell, P., 2007. Biofuels in the energy transition beyond peak oil. A macroscopic study of energy demand in the Stockholm transport system 2030. Energy 32, 2089-2098.

Robèrt, M., Jonsson, R.D., 2006. Assessment of transport policies toward future emission targets. A backcasting approach for Stockholm 2030. J Environ Assess Policy Manage 8, 451478.

Robinson, J.B., 1990. Futures under glass: A recipe for people who hate to predict. Futures $22,820-842$.

Rouillard, J.J., Heal, K.V., Ball, T., Reeves, A.D., 2013. Policy integration for adaptive water governance: Learning from Scotland's experience. Environ Sci Policy 33, 378-387.

Safarianova, S., Noembrini, F., Boulouchos, K., Dietrich, P., 2009. Techno-economic analysis of low-GHG emission light, medium and heavy duty vehicles. ETH Zurich, FP7-TPT-2008RTD-1.

SCB (Statistics Sweden), 2011. Fordonsstatistik. Fordon i län och kommun vid årsskiftet 2010/2011. [Vehicle statistics. Vehicles in counties and municipalities year-end 2010]. In Swedish. Stockholm, Sweden.

SEA (Swedish Energy Agency), 2012. Energy in Sweden 2012. Report ET 2012:34.

SEA (Swedish Energy Agency), 2013. Analys av marknaderna för biodrivmedel. [Analysis of the biofuel markets]. In Swedish. Report ES 2013:08.

Searchinger, T., Heimlich, R., Houghton, R.A., Dong, F., Elobeid, A., Fabiosa, J., Tokgoz, S., Hayes, D., Yu, T.-H., 2008. Use of U.S. croplands for biofuels increases greenhouse gases through emissions from land-use change. Science 319, 1238-1240.

Smith, B.C., 1976. Policy Making in British Government. London, Martin Robertson.

Söderberg, C., 2011. Institutional conditions for multi-sector environmental policy integration in Swedish bioenergy policy. Environ Polit 20, 528-546.

Söderholm, P., 2012. Ett mål flera medel - Styrmedelkombinationer i klimatpolitiken [One goal, several means - Combinations of incentives in climate policy]. In Swedish. Swedish Environmental Protection Agency, Report 6491. 
Stead, D., 2008. Institutional aspects of integrating transport, environment and health policies. Transp Policy 15, 139-148.

Stockholm County Administration Board, 2010. Länsplan för regional transportinfrastruktur i Stockholms län 2010-202. [County plan for regional transport infrastructure in Stockholm County 2010-2021]. In Swedish.

Stockholmsförhandlingen, 2007. Samlad trafiklösning Stockholmsregionen för miljö och tillväxt - till 2020 med utblick mot 2030. [Joint transport solution for environment and development in the Stockholm region: Until 2020 and towards 2030]. In Swedish.

Svenska dagbladet, 2008. Årets bild är en miljökatastrof . [Picture of the year is an environmental disaster]. In Swedish. Available at http://www.svd.se/kultur/miljokatastrofpa-arets-bild_951277.svd. Accessed 2013-12-10.

Swedish Government, 2009. Proposition 2008/09:162. En sammanhållen klimat- och energipolitik - klimat [Bill 2008/09:162. A joint climate and energy policy-climate]. In Swedish.

Swedish Government, 2013. Fossilfrihet på väg. [On fossil-free road]. In Swedish. SOU 2013:84.

Transport Analysis, 2013. Körsträckor 2010. [Driving distances 2010]. Available at http://trafa.se/PageDocuments/2010.xls. Accessed 2014-03-04.

Tuominen, A., Himanen, V., 2007. Assessing the interaction between transport policy targets and policy implementation - A Finnish case study. Transp Policy 14, 388-398.

Turton, H., 2006. Sustainable global automobile transport in the $21^{\text {st }}$ century: An integrated scenario analysis. Technol Forecast Soc 73, 607-629.

Underdal, A., 1980. Integrated marine policy. What? Why? How? Mar Policy 4, 159-169.

Wetterlund, E., Pettersson, K., Harvey, S., 2011. Systems analysis of integrating biomass gasification with pulp and paper production - Effects on economic performance, $\mathrm{CO}_{2}$ emissions and energy use. Energy 36, 932-941.

World Bank, 2008. World Development Report: Reshaping Economic Geography. Washington DC, United States.

Yang, C., McCollum, D., McCarthy, R., Leighty, W., 2009. Meeting an 80\% reduction in greenhouse gas emissions from transportation by 2050: a case study in California, USA. Transport Res D-Tr E 14, 147-156. 